\title{
Impact of Women's Empowerment on Infant Mortality in Indonesia
}

\author{
Dampak Pemberdayaan Perempuan pada Kematian Bayi di Indonesia
}

\author{
Hanik Stiyaningsih, Febri Wicaksono
}

Institute of Statistics, Jakarta, Indonesia

\begin{abstract}
Women's autonomy and empowerment has generally been recognized as one of most important factors of development. A lack of autonomy and empowerment may lead to negative outcomes on child health and mortality. Yet no study to-date has analyzed links between women's empowerment and infant mortality in Indonesia. This study tried to fill this gap to investigate the effect of women's empowerment on infant mortality in Indonesia. Sample of 9,754 women aged 15-49 years who had their last childbirth in period 2007-2012 were drawn from 2012 Indonesia Demographic and Health Survey. Composite index was considered to measure women's empowerment. Eight indicators were considered to measure three dimensions of women's empowerment, namely participation in economic decision-making, participation in health decision-making, and autonomy in mobility. Furthermore, the binary logistic model had been specified and estimated to investigate the effect of women's empowerment on infant mortality. Results showed that women who were more empowered were significantly less likely to experience infant mortality. This highlights the importance of women's empowerment in efforts to reduce infant mortality.
\end{abstract}

Keywords: Demographic health survey, infant mortality, women's empowerment

\begin{abstract}
Abstrak
Secara umum, otonomi dan pemberdayaan perempuan menjadi salah satu faktor penting dalam pembangunan. Kurangnya otonomi dan pemberdayaan perempuan dapat menyebabkan hasil negatif pada kesehatan dan kematian anak. Belum terdapat penelitian terkini yang menganalisis hubungan antara pemberdayaan perempuan dan kematian bayi di Indonesia. Penelitian ini berusaha mengisi kekosongan tersebut dengan menelusuri pengaruh pemberdayaan perempuan terhadap kematian bayi di Indonesia. Sampel berjumlah 9.754 perempuan berusia 15-49 tahun yang terakhir melahirkan pada periode tahun 20072012 diambil dari Survei Demografi dan Kesehatan Indonesia 2012. Pemberdayaan perempuan diukur dengan menggunakan indeks komposit yang dibangun dari delapan indikator dari tiga dimensi pemberdayaan perempuan, yaitu partisipasi dalam pengambilan keputusan di bidang ekonomi, partisipasi dalam pengambilan keputusan di bidang kesehatan, dan kebebasan untuk berpindah. Selanjutnya, estimasi dampak pemberdayaan perempuan pada kematian bayi menggunakan model regresi logistik. Hasil penelitian menunjukkan bahwa perempuan dengan tingkat pemberdayaan yang lebih baik akan memiliki peluang yang lebih rendah untuk mengalami kejadian kematian bayi. Hal ini menekankan pentingnya pemberdayaan perempuan untuk mengurangi kematian bayi. Kata kunci: Survei demografi kesehatan, kematian bayi, pemberdayaan perempuan
\end{abstract}

How to Cite: Stiyaningsih H, Wicaksono F. Impact of women's empowerment on infant mortality in Indonesia. Kesmas: National Public Health Journal. 2017; 11 (4): 185-191. (doi:10.21109/kesmas. v11i4.1259)
Correspondence: Febri Wicaksono, Institute of Statistics, Otto Iskandardinata street No.64C, Jakarta, Phone: +62218191437, e-mail: febri@stis.ac.id

Received: November $15^{\text {th }} 2016$

Revised: February 27th 2017

Accepted: April 3 2017 


\section{Introduction}

Infant mortality rate (IMR), defined as the number of infant deaths per 1,000 live births, is widely used as an indicator of health status of all populations as well as the development level of a country. High IMR is strongly related to low general living condition, low social well-being, low quality of environment, and low level of economic development that affect the health of the entire population. ${ }^{1}$

The high IMR, particularly in developing countries, has become one of the world's major concerns. Efforts are being made and strategies are being developed across all developing countries to reduce IMR to an acceptable level. The United Nation's Millennium Development Goal 4 (MDG4) set the target to reduce the under-five mortality rate by two-thirds by 2015 from 1990 level. Meanwhile, the United Nation's Sustainable Development Goal 3 (SDG3) set the target to reduce the underfive mortality rate to at least as low as 25 per 1,000 live births.

Indonesia has experienced a decrease in IMR from 68 deaths per 1,000 live births in 1991 to 32 deaths per 1,000 live births in 2012. ${ }^{2}$ However, despite having experienced a decline in IMR overtime, childhood mortality remains a public-health problem in Indonesia. IMR remains high in Indonesia compared to other Southest Asian countries. ${ }^{3}$

Meanwhile, ever since the 1994 International Conference on Population and Development in Cairo, women's autonomy and empowerment has been recognized as one of the most important factors of development and thus, it is identified as one of the development goals of national governments and international agencies. ${ }^{4}$ Many researchers have argued that women's empowerment is closely linked to positive outcomes for families and societies. ${ }^{5}$ Numerous studies have documented the role and importance of women for the health and overall well-being of their children and family members. ${ }^{6-13}$

Empowered women, particularly those who are more autonomous, have increased bargaining power, relative to their husbands. It has often been argued that child health and investments in children are determined by intrahousehold resource allocation decisions, which are related to gender inequalities in the household. Thus, women's autonomy and empowerment can result in a decline in fertility and in child mortality rates. ${ }^{14}$

However, no study to-date has examined links between women's empowerment and infant mortality in Indonesia even though in some communities, empowering women may result in lowering infant mortality. $6,7,9,13$

There is considerable variation in the definition and conceptualization of women's empowerment. The United
Nations Development Fund for Women (UNIFEM) has defined women's empowerment as "having access to and control over the means to make a living on a sustainable and long term basis, and receiving the material benefits of this access and control". ${ }^{15}$ World Bank defined empowerment as the "expansion of freedom of choice and action to shape one's life". ${ }^{16}$ Women's empowerment has also been defined as "an extension of a woman's ability to make strategic life choices in which these capabilities denied to her". 17

Measuring empowerment has proven difficult for several reasons. ${ }^{4,18}$ Malhotra and Schuler, ${ }^{4}$ have synthesized the six most common dimensions used to measure women's empowerment as economic, socio-cultural, familial/interpersonal, legal, political and psychological. However, most frequently used indicators to measure empowerment in individual/household level are domestic decision-making, access to or control over resources, and mobility/freedom of movement.

The aim of this study was to investigate the effect of women's empowerment on infant mortality in Indonesia. This study hypothesized that women who were more empowered were less likely to experience infant mortality.

\section{Method}

This study used data from 2012 Indonesia Demographic and Health Survey. Demographic and Health Survey are nationally-representative household survey that provides data for a wide range of monitoring and impact evaluation indicators in the areas of population, health, and nutrition. This survey used a three-stage sampling technique by probability proportional to size to select a sample of 46,000 households spread across Indonesia. There were 55,200 women aged 15-49 years old selected for this survey. In this study, the unit of analysis was women who had their last childbirth in period 2007-2012. With this limitation, there were 9,754 women aged 15-49 years old. Infant mortality for the last child of a woman was the primary outcome of the analysis. The response options were yes $(\operatorname{code}=1)$ and no ( code $=0$ ).

The key explanatory variable that was investigated in this study was women's empowerment. Women's empowerment was measured on the individual level. Adapting from Malhotra and Schuler, ${ }^{4}$ and Haque, et al, ${ }^{19}$ this study used three dimensions to measure women's empowerment which were economic decision making, health decision making, and physical mobility dimensions. Economic decision making dimension was assessed using three questions related to a woman's economic decision making (household purchases, husband's income use, and her income use) relative to her husband. Health decision making dimension was assessed using three questions related to a woman's health decision ma- 
king relative to her husband. Physical movement dimension was assessed using two questions related to a woman physical movement decision making (visit to family or relative, visit to health center alone) relative to her husband.

Women's empowerment index was constructed following Human Development Index (HDI) made by the United Nations Development Program, ${ }^{20}$ using the formula as seen in Equation 1.

The actual score of each dimension is calculated by summing the positive responses of the respondents in favor of their empowerment or autonomy. Maximum score of each dimension is the total number of indicators belonging to that dimension and minimum score is zero with all negative response. The value of those indices ranges from zero to one and one minus the indices value measures the gap of empowerment or autonomy. Then women's empowerment index was calculated by averaging those three dimension indexes. The women's empowerment index was classified into three categories that were low (if the index score less than 0.5), middle (if the index score 0.5 to 0.8 ), and high (if the index score more than 0.8 ) as UNDP did to HDI. ${ }^{20}$

Moreover, age at delivery, educational level, interval from previous birth, parity, sex of child, birth attendant, and antenatal care visits were also considered as important factors affecting infant mortality. ${ }^{9,21-26}$

This study used multivariate binary logistic regression model to identify the impact of women's empowerment and other factors on infant mortality. Binary logistic regression is a statistical method for analyzing a dataset in which there are one or more independent variables that determine an outcome. The outcome was measured with a dichotomous variable (in which there are only two possible outcomes). ${ }^{27}$ This study took a consideration of using forward method for modeling the regression. ${ }^{27}$ The model used in this study can be formulated as Equation 2 , where $\pi(\chi)$ is probability to use a skilled birth attendant during delivery, $\beta_{0}$ is a constant to be estimated, $\beta p$ are parameters to be estimated, and $\chi_{p}$ represents independent variables.

\section{Results}

Table 1 presents the sample characteristics. As many as 227 women $(2.3 \%)$ who had their last childbirth in period 2007-2012 had experienced infant mortality in their last birth. Meanwhile, women who had their last childbirth in period 2007-2012 mostly had delivery at the age of $20-35$ years old $(77.5 \%)$, attained secondary or higher education $(61.0 \%)$, had two years or more birth interval from previous birth $(93.4 \%)$, had less than four parities $(73.2 \%)$, gave male baby birth (51.90), assisted by skilled birth attendant $(78.0 \%)$, and visited four times or more antenatal care $(82.0 \%)$.
Figure 1 presents the women's empowerment index. There were $32.8 \%$ of women had low empowerment index, $58.9 \%$ of women had middle empowerment index, and $8.3 \%$ of women had high empowerment index.

Women who had their last childbirth in period 20072012 mostly had not experienced infant mortality $(97.7 \%)$. However, the proportion of women who had experienced infant mortality decreased with the increase of women's empowerment index (Table 2). The bivariate logistic regression showed that women's empowerment significantly affected women's experience of infant mortality. The odds of infant mortality experienced were more than eight times lower $(1 / 0.119=8.4)$ for women who had high empowerment than for those who had low empowerment with odds ratio (OR) 0.12 and 95\% con-

$$
\begin{gathered}
\text { Dimension Index }=\frac{\text { Actual Score }- \text { Minimum Score }}{\substack{\text { Maximum Score }- \text { Minimum Score } \\
\text { Equation }}} \\
\ln \left(\frac{\pi(x)}{1-\pi(x)}\right)=\beta_{0}+\beta_{1} x_{1}+\cdots+\beta_{p} x_{p}
\end{gathered}
$$

Equation 2

Table 1. Sample Characteristics

\begin{tabular}{llrr}
\hline Variable & Category & n & $\%$ \\
\hline Sample size & & 9,754 & 100.0 \\
Infant mortality experience & Yes & 227 & 2.3 \\
& No & 9,527 & 97.7 \\
Age at delivery & $20-35$ years old & 7,561 & 77.5 \\
\multirow{2}{*}{ Education } & $<20$ or $>35$ years old & 2,193 & 22.5 \\
& Secondary or higher & 5,950 & 61.0 \\
Birth interval from previous birth & Less than secondary & 3,804 & 39.0 \\
& 2 years or more & 9,112 & 93.4 \\
Parity & Less than 2 years & 642 & 6.6 \\
\multirow{3}{*}{ Sex of child } & Less than 4 & 7,142 & 73.2 \\
\multirow{2}{*}{ Assisted by skilled birth attendant } & More than 4 & 2,612 & 26.8 \\
\multirow{2}{*}{ Antenatal care visits } & Mes & 4,692 & 48.1 \\
& No & 5,062 & 51.9 \\
& 4 times or more & 7,615 & 78.1 \\
& Less than 4 times & 2,139 & 21.9 \\
& & 8,004 & 82.1 \\
& & 1,750 & 17.9 \\
\hline
\end{tabular}

Notes:

$\mathrm{n}=$ Number of Sample; $\%=$ Percentage

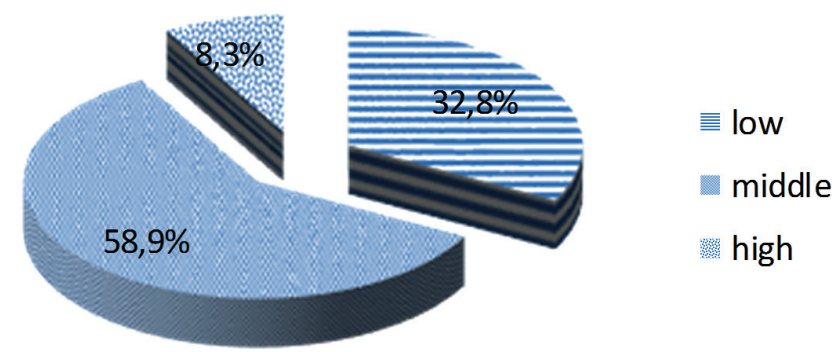

Figure 1. Women Distribution by Women' Empowerment Index 
Table 2. Distribution of Women Who Had Experienced Infant Mortality by Women's Empowerment Index

\begin{tabular}{|c|c|c|c|c|c|c|}
\hline \multirow{3}{*}{$\begin{array}{l}\text { Women's Empowerment } \\
\text { Index }\end{array}$} & \multicolumn{4}{|c|}{ Infant Mortality Experience } & & \\
\hline & \multicolumn{2}{|c|}{ No } & \multicolumn{2}{|c|}{ Yes } & \multicolumn{2}{|c|}{ Total } \\
\hline & $\mathbf{n}$ & $\%$ & $\mathbf{n}$ & $\%$ & $\mathbf{n}$ & $\%$ \\
\hline High & 805 & 99.5 & 4 & 0.5 & 809 & 100.0 \\
\hline Middle & 5,653 & 98.4 & 95 & 1.7 & 5,748 & 100.0 \\
\hline Low & 3,069 & 96.0 & 128 & 4.0 & 3,197 & 100.0 \\
\hline Total & 9,527 & 97.9 & 227 & 2.3 & 9,754 & 100.0 \\
\hline
\end{tabular}

Table 3. Determinants of Infant Mortality (Bivariate Model)

\begin{tabular}{|c|c|c|c|c|c|c|}
\hline Variables & Category & Coef & Standard Error & p Value & Odds Ratio & $95 \% \mathrm{CI}$ \\
\hline Women's empowerment & $\begin{array}{l}\text { High } \\
\text { Middle } \\
\text { Low (ref.) }\end{array}$ & $\begin{array}{l}-2.13 \\
-0.91\end{array}$ & $\begin{array}{l}0.51 \\
0.14\end{array}$ & $\begin{array}{l}\left.0.000^{*}\right) \\
\left.0.000^{*}\right)\end{array}$ & $\begin{array}{l}0.12 \\
0.40\end{array}$ & $\begin{array}{l}0.04-0.32 \\
0.31-0.53\end{array}$ \\
\hline Age at delivery & $\begin{array}{l}20-35 \\
<20 \text { or }>35 \text { (ref.) }\end{array}$ & -0.77 & 0.14 & $\left.0.000^{*}\right)$ & 0.47 & $0.36-0.61$ \\
\hline Education & $\begin{array}{l}\text { Secondary or higher } \\
\text { Less than secondary (ref.) }\end{array}$ & -0.45 & 0.13 & $\left.0.001^{*}\right)$ & 0.64 & $0.49-0.83$ \\
\hline Birth interval from previous birth & $\begin{array}{l}2 \text { years or more } \\
\text { Less than } 2 \text { years (ref.) }\end{array}$ & -1.22 & 0.18 & $\left.0.000^{*}\right)$ & 0.30 & $0.21-0.42$ \\
\hline Parity & $\begin{array}{l}\text { Less than } 4 \\
\text { More than } 4 \text { (ref.) }\end{array}$ & -0.73 & 0.14 & $\left.0.000^{*}\right)$ & 0.49 & $0.37-0.63$ \\
\hline Sex of child & $\begin{array}{l}\text { Female } \\
\text { Male (ref.) }\end{array}$ & -0.32 & 0.14 & $\left.0.021^{*}\right)$ & 0.73 & $0.56-0.95$ \\
\hline Assisted by skilled birth attendant & $\begin{array}{l}\text { Yes } \\
\text { No (ref.) }\end{array}$ & -0.78 & 0.14 & $0.000 *)$ & 0.46 & $0.35-0.60$ \\
\hline Antenatal care visits & $\begin{array}{l}4 \text { times or more } \\
\text { Less than } 4 \text { times (ref.) }\end{array}$ & -1.06 & 0.14 & $\left.0.000^{*}\right)$ & 0.35 & $0.26-0.46$ \\
\hline
\end{tabular}

Notes:

$\mathrm{CI}=$ Confidence Interval

*Significant with $\mathrm{p}$ value $<0.01$

fident interval (CI) $0.04-0.32$. Meanwhile, the odds of infant mortality experienced were more than two times lower $(1 / 0.40=2.5)$ for women who had middle empowerment than for those who had low empowerment (OR: $0.40,95 \% \mathrm{CI}=0.31-0.53$ ).

As presented in Table 3, the bivariate logistic regression also showed that age at delivery, educational level, birth interval, parity, sex of child, skilled birth attendant, and antenatal care visits significantly affected the women's experience of infant mortality ( $\mathrm{p}$ value $<0.05$ ).

Meanwhile, six variables were found to be statistically significant ( $\mathrm{p}$ value $<0.05$ ) that affected the women's experience of infant mortality in multivariate model. They were women's empowerment, age at delivery, birth interval, sex of child, skilled birth attendant, and antenatal care visits (Table 4).

After adjustment for other factors (Table 4), women's empowerment significantly affected infant mortality. The odds of infant mortality experienced were more than seven times lower $(1 / 0.14=7.1)$ for women who had high empowerment than for those who had low empowerment $\left(\mathrm{OR}_{\mathrm{adj}}: 0.14,95 \% \mathrm{CI}=0.05-0.38\right)$. Meanwhile, the odds of infant mortality experienced were more than two times lower $(1 / 0.42=2.4)$ for women who had middle empowerment than for those who had low empowerment $\left(\mathrm{OR}_{\mathrm{adj}}: 0.42,95 \% \mathrm{CI}=0.32-0.55\right)$.

Besides, as shown in Table 4, holding all other factors constant, women who delivered at age of 20-35 years old had lower odds to have experienced infant mortality than those delivered at age younger than 20 years or older than 35 years. Women who had two years or more birth intervals from previous birth for their last birth had lower odds to have experienced infant mortality than those had less than two-year birth intervals from previous birth for their last birth. Women who had female children had lower odds to have experienced infant mortality than those had male child. Women who were assisted by skilled birth attendant during delivery had lower odds to have experienced infant mortality than those who were not assisted by skilled birth attendant during delivery. 
Table 4. Determinants of Infant Mortality (Multivariate Model)

\begin{tabular}{llccccc}
\hline Variables & Category & Coef & Standard Error & $\mathbf{p}$ Value & Adjusted Odds & 95\% CI \\
\hline Women's empowerment & High & -1.97 & 0.51 & $\left.0.000^{*}\right)$ & 0.14 & $0.05-0.38$ \\
& Middle & -0.87 & 0.14 & $\left.0.000^{*}\right)$ & 0.42 & $0.32-0.55$ \\
Age at delivery & $\begin{array}{l}\text { Low (ref.) } \\
20-35\end{array}$ & -0.76 & 0.14 & $\left.0.000^{*}\right)$ & 0.47 & $0.35-0.62$ \\
Birth interval from previous birth & $\begin{array}{l}<20 \text { or }>35 \text { (ref.) } \\
\text { 2 years or more }\end{array}$ & -1.13 & 0.18 & $\left.0.000^{*}\right)$ & 0.32 & $0.23-0.46$ \\
Sex of child & $\begin{array}{l}\text { Less than 2 years (ref.) } \\
\text { Female }\end{array}$ & -0.28 & 0.14 & $\left.0.043^{* *}\right)$ & 0.76 & $0.58-0.99$ \\
Assisted by skilled birth attendant & $\begin{array}{l}\text { Male (ref.) } \\
\text { Yes }\end{array}$ & -0.38 & 0.16 & $\left.0.016^{* *}\right)$ & 0.50 & $0.50-0.93$ \\
Antenatal care visits & $\begin{array}{l}\text { No (ref.) } \\
\text { 4 times or more } \\
\text { Less than 4 times (ref.) }\end{array}$ & -0.71 & 0.16 & $\left.0.000^{*}\right)$ & 0.36 & $0.36-0.67$ \\
& & & & & \\
\hline
\end{tabular}

Notes:

$\mathrm{CI}=$ Confidence Interval

*Significant with $\mathrm{p}$ value $<0.01,{ }^{* * *}$ Significant with $\mathrm{p}$ value $<0.05$

Women who attended four or more antenatal care visits also had lower odds of infant mortality than those who attended less than 4 times.

\section{Discussion}

This study is the first to-date to examine relation between women's empowerment and infant mortality in Indonesia. Prior analysis was built by including a composite empowerment measure from three dimensions of empowerment in addition to examining direct contribution of women's empowerment to infant mortality.

Key finding showed that women who were more empowered were less likely to experience infant mortality. This finding reinforces other studies showing that women were more likely to have better outcomes in child health when they were more empowered.6,7,9,13,28,29

The care that children receive, particularly infants, is a result of their household circumstances. In many societies, women are the primary caretakers of children. Thus, redirecting of decision-making roles in favor of women potentially improve child health outcomes. ${ }^{7}$

Further, child health, particularly in the early stages of life, is directly and indirectly affected by mothers' health care before, during and after pregnancy. ${ }^{30}$ Thus limiting control over health care decision of women can increase the likelihood of infant mortality.

Moreover, delays in taking children to receive health care due to consulting other family members may lead to increased health issues. Thus, women who can make independent decisions about health care, especially concerning their children, may have better child mortality outcomes. ${ }^{31}$

Furthermore, studies from both developing and developed countries consistently show that the share of assets owned by women could affect household expenditure patterns. ${ }^{32}$ When mothers' control over resources in- creases, households allocate more resources to children's health and education. 33-35 Women who are more empowered are able to make positive investments in their children, thus it can increase the probability of child survival. ${ }^{36}$ Women who are less empowered will have limited access to financial and educational resources, thus it can decrease the probability of survival for their children. ${ }^{10}$

In the multivariate analysis, this study found that age at delivery, birth interval, sex of child, skilled birth attendant, and antenatal care visits were significantly associated with women's experience of infant mortality. This finding is in line with the findings of other researchers. 9,21-26

This study also found that infants from women aged 20-24 years old were less likely to die before reaching their first birthday. Child mortality is higher in women who give birth at too young age and too old age which may be related to biological factors that can lead to the occurrence of complications during pregnancy and at delivery. ${ }^{2}$ Young adolescents do not yet have a fully developed pelvis. Pregnancy for them can result in serious consequences, such as eclampsia, premature labor, prolonged labor, obstructed labor, fistula, anemia (thin blood) or infant and/or maternal death. Meanwhile, after the age of 35 , the health risks associated with pregnancy and childbirth begin to increase again. The risks may include hypertension (high blood pressure), hemorrhage (loss of blood), miscarriage and gestational diabetes (diabetes during pregnancy) for the woman and congenital anomalies (birth defects) for the child. ${ }^{37-38}$ This finding is in line with study by Ardhikari and Sawangdee, ${ }^{9}$ Joshua and Van Ginneken, ${ }^{21}$ and Prameswari. 22

Short birth interval may reduce mothers' recovery time leading to adverse perinatal outcomes. This study is line with previous studies that found significant associa- 
tion between short birth interval and greater risk for adverse perinatal outcomes, such as preterm birth, low birth weight, and small size for gestational age. ${ }^{23-24}$

Boys and girls have different probabilities of death due to biological factors, and these differences vary between infancy and early childhood. ${ }^{25}$ This finding is in line with study by Mustafa and Odimegwu, ${ }^{26}$ in Kenya which found that boys were more likely to die before reaching their first birthday.

Antenatal care visits and birth attendant also significantly affected infant mortality. These findings are in line with previous studies in Indonesia. ${ }^{22-23}$ Visiting antenatal care can make known early stage pregnancy complications. Meanwhile, skilled health professionals can administer interventions to prevent and manage lifethreatening complications, such as heavy bleeding, or refer the patient to a higher level of care when needed. 39 Thus, visiting antenatal care and delivery assisted by skilled birth attendants can lead to higher survival probability for infants.

\section{Conclusion}

This study is the first to-date to examine the relation between women's empowerment and infant mortality in Indonesia. The findings contribute to the existing literature by providing empirical evidence on relation between women's empowerment and infant mortality. This study has shown that women who are more empowered have better outcomes on child health, especially in reducing infant mortality. In addition, infant mortality is also affected by age at delivery, birth interval, sex of child, skilled birth attendant, and antenatal care visits. The findings strongly indicate the need for policy promoting women's empowerment to improve achievement in health development, especially in reducing infant and child mortality.

\section{References}

1. Reidpath DD, Allotey P. Infant mortality rate as an indicator of population health. Journal of Epidemiology and Community Health. 2003; 57(5): 344-6.

2. Statistics Indonesia, National Population and Family Planning Board, Indonesia Ministry of Health, ICF International. Indonesia demographic and health survey 2012. 2013 [cited 2016 September 5]. Available from: http://www.dhsprogram.com

3. Kementerian Kesehatan Republik Indonesia. Profil kesehatan Indonesia tahun 2012. Jakarta: Kementerian Kesehatan Republik Indonesia; 2013.

4. Malhotra A, Schuler S. Women's empowerment as a variable in international development. Washington DC: World Bank; 2005.

5. Presser H, Sen G, eds. Women's empowerment and demographic processes: moving beyond Cairo. New York: Oxford University Press; 2000.

6. Boehmer U, Williamson JB. The impact of woman's status on infant mortality rate: a cross-national analysis. Social Indicator Research.
1996; 37: 333-60.

7. Maitra P. Parental bargaining, health inputs and child mortality in India. Journal of Health Economics. 2004; 23: 259-91.

8. Shroff M, Griffiths P, Adiar L, Suchandran C, Bentley M. Maternal autonomy is inversely related to child stunting in Andhra Pradesh, India. Maternal Child Nutrition. 2009; 5 (1): 64- 74.

9. Ardhikari R, Sawangdee Y. Influence of women's autonomy on infant mortality in Nepal. Reproductive Health. 2011; 8 (7).

10. Folaranmi OO. Women empowerment as a determinant of investments in children in selected rural communities in Nigeria. An International Multidisciplinary Journal. 2013; 7(4): 138-61.

11. Imai KS, Annim SK, Kulkarni VS, Gaiha R. Women's empowerment and prevalence of stunted and underweight children in Rural India. World Development. 2014; 62(10): 88-105.

12. Cunningham K, Ploubidis GB, Menon P, Ruel M, Kadiyala S, Uauy R, Ferguson E. Women's empowerment in agriculture and child nutritional status in rural Nepal. Public Health Nutrition. 2015; 18(17): 3134-45.

13. Burroway R. Women's rights save lives: a cross-national analysis of infant and child mortality and women's access to land, property, and loans in developing countries. Sociology of Development. 2015; 1(4): 418-41.

14. Eswaran. The empowerment of women, fertility, and child mortality: towards a theoretical analysis. Journal Population Economy. 2000; 15: 433-54.

15. Carr M. Women's economic empowerment: key to development. In women's empowerment and economic justice; reflecting on experience in Latin America and the Caribbean, De Pauli L (ed). New York: United Nations Development Fund for Women (UNIFEM); 2000.

16. Narayan D, ed. Empowerment and poverty reduction: a sourcebook. Washington, DC: World Bank; 2002.

17. Kabeer N. Reflection on the measurement of women's empowerment. In discussing women's empowerment-theory and practice. Stockholm: Swedish International Development Cooperation Agency; 2001.

18. Mason KO, Smith HL. Women's empowerment and social context: results from five asian countries. Washington DC: World Bank; 2003.

19. Haque MM, Islam TM, Tareque MI, Mostofa MG. Women's empowerment or autonomy: a comparative view in Bangladesh context. Bangladesh e-Journal of Sosiology. 2011; 8 (2): 17-30.

20. United Nations Development Programme (UNDP). Human development report 2005. New York: United Nations Development Programme (UNDP); 2005.

21. Joshua K, Van Ginneken JK. Determinants of infant and child mortality in Zimbabwe: results of multivariate hazard analysis. Demographic Research. 2009; 21(13): 367-70.

22. Prameswari MF. Kematian perinatal di Indonesia dan faktor yang berhubungan, tahun 1997-2003. Kesmas: National Public Health Journal. 2007; 1(4): 154-60.

23. Simbolon D. Kelangsungan hidup bayi di perkotaan dan pedesaan Indonesia. Kesmas: National Public Health Journal. 2006; 1(1): 3-10.

24. Conde-Agudelo A, Rosas-Bermudez A, Kafury-Goeta AC. Birth spacing and risk of adverse perinatal outcomes: a meta-analysis. JAMA. 2006; 295(15): 1809-23.

25. Sawyer CC. Child mortality estimation: estimating sex differences in childhood mortality since the 1970s. PLoS Med. 2012; 9(8): e1001287. 
26. Mustafa HE, Odimegwu C. Socioeconomic determinants of infant mortality in Kenya: Analysis of Kenya DHS 2003. Journal of Humanities \& Social Sciences. 2008; 2(2).

27. Kleinbaum DG. Logistic regression: a self-learning text. 2nd ed. New York: Springer-Verlak Inc; 2010.

28. Hossain MB, Phillips JF, Pence B. The effect of women's status on infant and child mortality in four rural areas of Bangladesh. Journal of Biosocial Science. 2007; 39: 355-66.

29. Ibrahim A, Tripathi S, Kumar A. The effect of women's empowerment on child health status: study on two developing nations. International Journal of Scientific and Research Publications. 2015; 5 (4): 1-8.

30. Mosley WH, Chen LC. An analytical framework for the study of child survival in developing countries. Bulletin World Health Organization. 2003; 8 (12): 140-5.

31. Desai S, Johnson K. Women's decision-making and child health: familial and social hierarchies. In a focus on gender: collected papers on gender using DHS data. Calverton MD: ORC Macro; 2005.

32. Lundberg S, Pollak RA. Bargaining and distribution in marriage. Journal of Economic Perspectives. 1996; 10 (4): 139-58.

33. Hoddinott J, Haddad L. Does female income share influence household expenditures? evidence from Cote d'Ivoire. Oxford Bulletin of Economics and Statistics. 1995; 57 (1): 77-96.

34. Doss C. The effects of intrahousehold property ownership on expenditure patterns in Ghana. Journal of African Economies. 2005; 15: 149-80.

35. Duflo E, Udry C. Intrahousehold resource allocation in Cote D'ivoire: social norms, separate accounts and consumption choices. NBER Working Paper \#10498; 2004.

36. Durrant VL, Sathar ZA. Greater investments in children through women's empowerment a key to demographic change in Pakistan. Policy Research Division Working Paper. Washington DC: National Research Council, Committee on Population; 2000.

37. Huang L, Sauven R, Birkett N, Fergusson D, van Walraven C. Maternal age and risk of stillbirth: a systematic review. Canadian Medical Association Journal. 2008; 178 (2): 165-72.

38. Haavaldsen C, Sarfraz AA, Samuelsen SO, Eskild A. The impact of maternal age on fetal death: does length of gestation matter? American Journal of Obstetrics \& Gynecology. 2010; 203:554.e1-8.

39. World Health Organization. Making pregnancy safer: The critical role of the skilled attendant. Geneva: WHO, ICM, FIGO; 2004. 